Reprod. Nutr. Dévelop., 1981, 21 (6B), 1085-1093.

\title{
Comparative study of some characteristics of the semen of RR (rose comb) or rr (single comb) cockerels
}

\author{
by $M$. PETITJEAN, Madeleine SERVOUSE * \\ with the technical assistance of G. MALINEAU and M. MARCHAND
}

I.N.R.A., Domaine Expérimental du Magneraud, 17700 Surgères, France.

* U.E.R. Sciences Fondamentales ef Appliquées, Laboratoire de Biochimie 40, avenue du Recteur Pineau, 96022 Poitiers, France.

Summary. Comparative studies were made of semen samples from subfertile $R R$ and normally fertile $r$ cockerels. These samples were obtained either by abdominal massage or directly from the tip of papillae. The numbers of collected sperm did not differ between genotypes and the sperm from $R R$ cockerels were less motile than those from $r r$ cockerels irrespective of the semen collection method. The uric acid concentration of seminal plasma was influenced by the semen collection method (massage $>$ papillae) but no variations were induced by the genotypes. The ATP-ase and acid phosphatase activities found in the seminal plasma were influenced respectively by the genotype $(r r>R R)$ and the semen collection method (papillae $>$ massage). The fumarase and acrosin activities found in the sperm were not influenced by the semen collection methods while acrosin activity was found to be higher in $R R$ than in $r r$ cockerels. Correlations between these various characteristics are given in detail.

\section{Introduction.}

According to Cochez (1951) the low fecundity observed in the White Wyandotte breed is due to the subfertility of those cockerels which are homozygous for rose comb $(R R)$. This male subfertility influences both the egg fertility level and the duration of the fertile period in the hen (Crawford and Smyth, 1961a, b, c). A deficiency in the semen quality of $R R$ cockerels can explain their low fertility, because the sperm motility observed after dilution and storage of semen has been found to be subnormal (Petitjean and Cochez, 1966). The fumarase activity of sperm is also depressed in RR cockerels (Buckland et al., 1968). In contrast, no anomaly has been found in the seminal plasma of these cockerels (Crawford and Smyth, 1964c ; Peyre et al., 1968 ; Petitjean, 1970).

The present work reports a comparison of several biochemical constituents of semen collecied from $R R$ and $r$ cockerels : uric acid, ATP-ase, acid phosphatase fumarase and acrosine. Uric acid is a normal contaminant of semen collected by the 
massage method. ATP-ase and acid phosphatase are particle-linked enzymes found in the seminal plasma itself, while fumarase is chiefly an intracellular enzyme associated with mitochondria. Its activity could therefore explain the depressed motility of the sperm collected from RR cockerels. Acrosin was studied as it is a component of the acrosome.

\section{Materials and methods.}

Animals. - Cockerels from two lines were used (M88 S = single comb ; M88 $R=$ rose comb) derived from the M88 strain in which the males are $d w / d w$.

The experiments involved 29 cockerels of each line, at 22 weeks of age. They were raised under $16 \mathrm{hrs}$ of light daily, individually caged, with food and water available ad libitum.

Each line was divided into 4 groups of 7-8 cockerels. The ejaculates were pooled for each group. After 3 days of habituation to pelvic massage, sperm collections were carried out once a day for 4 consecutive days (D1 to D4). On the following day, the cockerels were killed and their semen was collected directly on the tip of their ejaculatory papillae at autopsy.

In each semen sample, the volume, the sperm concentration, the total number of spermatozoa and their motility was determined.

Semen sample preparation. - After centrifugation $\left(1500 \times \mathrm{g}, 10 \mathrm{~min}, 0^{\circ} \mathrm{C}\right)$ the seminal plasma was decanted, then filtered (Millipore, $0.45 \mu \mathrm{m}$ ) to eliminate any sperm debris. The sperm pellet was resuspended in phosphate buffer $\mathrm{pH} 7.0$ and centrifuged again. The filtered plasmas and the washed pellets were frozen, then stored at $-18^{\circ} \mathrm{C}$ until assayed.

\section{Assays.}

1) In the filtered frozen-thawed seminal plasma fractions, uric acid was assayed by the uricase method (Praetorius, 1963). Other fractions from each seminal plasma were centrifuged again after thawing at $40000 \times \mathrm{g}, 30 \mathrm{~min}$, at $0{ }^{\circ} \mathrm{C}$ to separate a particle pellet in which acid phosphatase and ATP-ase were assayed by spectrophotometry. The first enzyme (E.C. : 3.1.3.2) was assayed at $\lambda=400 \mathrm{~nm}$ in the presence of sodium paranitrophenyl phosphate $\left(4.75 \times 10^{-3} \mathrm{M}\right)$ in citrate buffer $\left(0.1 \mathrm{M}, \mathrm{pH}=5.25,25^{\circ} \mathrm{C}\right)$. The second enzyme (E.C. 3.6.1.3) was assayed at $\lambda=340 \mathrm{~nm}, \mathrm{pH}=8.0$, in the presence of ATP-Mg++ $\left(5 \times 10^{-4} \mathrm{M}\right)$ and the auxiliary enzymes pyruvate and lacticodehydrogenase (Horgan ef al., 1972).

2) After thawing, the sperm pellet was washed at $0^{\circ} \mathrm{C}$ using Tris- $\mathrm{HCl}$ buffer $(0.02 \mathrm{M}, \mathrm{pH}=8.2)$, then sonicated $(5 \times 30 \mathrm{sec}$ with $30 \mathrm{sec}$ of delay between consecutive treatments). The sonicated sperm were then centrifuged ( $30 \mathrm{~min}, 40000 \times \mathrm{g}, 0 \circ \mathrm{C}$ ). Two enzymes were assayed in the supernatant : 1) Fumarase (E.C. : 4.2.1.2) in the presence of 1-malate 0.05 M (Hill and Bradshow, 1969) ;2) Acrosine (E.C. : 3.4.21.10) in the presence of $\alpha-\mathrm{N}$-benzoyl-dl-arginine para nitroaniline $\mathrm{HCl}$ (DL-Bapna) $10^{-3} \mathrm{M}$, dissolved in 10 p. $100(\mathrm{~V} / \mathrm{V})$ dimethylsulfoxide and Tris- $\mathrm{HCl}$ buffer $(0.1 \mathrm{M}, \mathrm{pH}=8.2)$ (Erlanger ef al., 1961). 
Futhermore, uric acid $(\mathrm{mg} / \mathrm{l})$, acid phosphatase $\left(\mu \mathrm{m} / 10^{9}\right)$ and fumarase $\left(\mu \mathrm{M} / 10^{9}\right)$ were also assayed after extraction from the sperm cells.

An analysis of variance was performed using the following model :

$$
Y_{i j k l}=D_{i}+G_{j}+(D G)_{i j}+C_{j k}+(D C)_{i j k}+E_{i j k 1}
$$

where $D_{i}$ is the day of the semen collection $(i=1,2,3,4) ; G_{j}$, the genotype of the cockerels $(S$ or $R) ;(D G)_{i j}$, the day $\times$ genotype interaction ; $C_{j k}$, the $K^{0}$ group of cockerels within the $J^{\circ}$ genotype $;(D C)_{i j k}$, the day $\times$ group interaction ; $E_{i j k ~}$, residual assumed to be independent with a mean of zero and the same variance normally distributed; $Y_{i j k l}$, factor to be analyzed, for example no. of spermatozoa.

\section{Results.}

1. Ejaculates collected from the 1 st to the 4 th day (tables 1 and 2 ).

a) Biophysical observations. - There was no significant day $\times$ genotype interaction in the characteristics of ejaculates (volume, sperm concentration, total number of sperm per ejaculate, motility). The genotype strongly influenced the volume of ejacu-

TABLE 1

Characteristics of ejaculates of $R R$ and $r r$ cockerels collected over four consecutive days

\begin{tabular}{|c|c|c|c|c|c|c|c|c|c|}
\hline \multirow{3}{*}{$\begin{array}{c}\text { Characteristics } \\
\text { studied }\end{array}$} & \multirow{3}{*}{$\begin{array}{l}\text { Comb } \\
\text { geno- } \\
\text { type }\end{array}$} & \multicolumn{8}{|c|}{ Collection period } \\
\hline & & \multicolumn{2}{|c|}{ D 1} & \multicolumn{2}{|c|}{ D 2} & \multicolumn{2}{|c|}{ D 3} & \multicolumn{2}{|c|}{ D 4} \\
\hline & & $\bar{x}$ & (s) & $\bar{x}$ & $(s)$ & $\bar{x}$ & (s) & $\bar{x}$ & (s) \\
\hline Sample volume $(\mathrm{ml})$ & $\begin{array}{l}R R \\
r r\end{array}$ & $\begin{array}{l}2.563 \\
3.313\end{array}$ & $\begin{array}{l}(0.515) \\
(0.554)\end{array}$ & $\begin{array}{l}1.950 \\
2.300\end{array}$ & $\begin{array}{l}(0.311) \\
(0.183)\end{array}$ & $\begin{array}{l}1.425 \\
2.050\end{array}$ & $\begin{array}{l}(0.299) \\
(0.100)\end{array}$ & $\begin{array}{l}1.238 \\
2.075\end{array}$ & $\begin{array}{l}(0.206) \\
(0.189)\end{array}$ \\
\hline Sperm./ml. $\left(.10^{9}\right)$ & $\begin{array}{l}R R \\
r r\end{array}$ & $\begin{array}{l}2.985 \\
2.853\end{array}$ & $\begin{array}{l}(0.750) \\
(0.358)\end{array}$ & $\begin{array}{l}2.690 \\
2.565\end{array}$ & $\begin{array}{l}(0.816) \\
(0.373)\end{array}$ & $\begin{array}{l}3.165 \\
2.810\end{array}$ & $\begin{array}{l}(0.902) \\
(0.353)\end{array}$ & $\begin{array}{l}2.775 \\
2.228\end{array}$ & $\begin{array}{l}(0.773) \\
(0.493)\end{array}$ \\
\hline $\begin{array}{l}\text { Total sperm per } \\
\text { sample }\left(.10^{9}\right)\end{array}$ & $\begin{array}{l}R R \\
r r\end{array}$ & $\begin{array}{l}7.515 \\
9.558\end{array}$ & $\begin{array}{l}(2.236) \\
(2.437)\end{array}$ & $\begin{array}{l}5.090 \\
5.928\end{array}$ & $\begin{array}{l}(1.147) \\
(1.364)\end{array}$ & $\begin{array}{l}4.368 \\
5.765\end{array}$ & $\begin{array}{l}(0.882) \\
(0.843)\end{array}$ & $\begin{array}{l}3.338 \\
4.643\end{array}$ & $\begin{array}{l}(0.524) \\
(1.245)\end{array}$ \\
\hline Motility & $\begin{array}{l}R R \\
r r\end{array}$ & $\begin{array}{l}12.5 \\
39.2\end{array}$ & $\begin{array}{l}(14.5) \\
(15.0)\end{array}$ & $\begin{array}{l}11.4 \\
47.5\end{array}$ & $\begin{array}{l}(7.1) \\
(6.1)\end{array}$ & $\begin{array}{l}20.2 \\
52.0\end{array}$ & $\begin{array}{l}(13.2) \\
(14.0)\end{array}$ & $\begin{array}{l}14.7 \\
51.1\end{array}$ & $\begin{array}{l}(10.1) \\
(12.4)\end{array}$ \\
\hline Uric acid $(\mathrm{mg} / \mathrm{l})$ & $\begin{array}{l}R R \\
r r\end{array}$ & $\begin{array}{l}562 \\
438\end{array}$ & $\begin{array}{l}(230) \\
(221)\end{array}$ & $\begin{array}{l}256 \\
347\end{array}$ & $\begin{array}{l}(171) \\
(189)\end{array}$ & $\begin{array}{l}261 \\
291\end{array}$ & $\begin{array}{l}(180) \\
(166)\end{array}$ & $\begin{array}{l}320 \\
424\end{array}$ & $\begin{array}{l}(162) \\
(95)\end{array}$ \\
\hline $\begin{array}{l}\text { Acid phosphatase } \\
(\mu \mathrm{W} / \mathrm{ml})\end{array}$ & $\begin{array}{l}R R \\
r r\end{array}$ & $\begin{array}{l}2.686 \\
2.739\end{array}$ & $\begin{array}{l}(0.430) \\
(0.269)\end{array}$ & $\begin{array}{l}2.578 \\
2.041\end{array}$ & $\begin{array}{l}(0.537) \\
(0.215)\end{array}$ & $\begin{array}{l}2.310 \\
2.632\end{array}$ & $\begin{array}{l}(0.376) \\
(0.322)\end{array}$ & $\begin{array}{l}2.041 \\
2.417\end{array}$ & $\begin{array}{l}(0.107) \\
(0.483)\end{array}$ \\
\hline ATP-ase $(\mu \mathrm{M} / \mathrm{ml})$ & $\begin{array}{l}R R \\
r r\end{array}$ & $\begin{array}{l}1.483 \\
1.645\end{array}$ & $\begin{array}{l}(0.038) \\
(0.384)\end{array}$ & $\begin{array}{l}1.100 \\
1.315\end{array}$ & $\begin{array}{l}(0.215) \\
(0.024)\end{array}$ & $\begin{array}{l}1.043 \\
1.473\end{array}$ & $\begin{array}{l}(0.295) \\
(0.162)\end{array}$ & $\begin{array}{l}1.128 \\
1.525\end{array}$ & $\begin{array}{l}(0.180) \\
(0.146)\end{array}$ \\
\hline $\begin{array}{l}\text { Acrosine } \\
\left(\mu \mathrm{W} \cdot 10^{9} \mathrm{spz}\right)\end{array}$ & $\begin{array}{l}R R \\
r r\end{array}$ & $\begin{array}{l}0.466 \\
0.337\end{array}$ & $\begin{array}{l}(0.177) \\
(0.190)\end{array}$ & $\begin{array}{l}0.533 \\
0.490\end{array}$ & $\begin{array}{l}(0.097) \\
(0.193)\end{array}$ & $\begin{array}{l}0.352 \\
0.444\end{array}$ & $\begin{array}{l}(0.109) \\
(0.116)\end{array}$ & $\begin{array}{l}0.404 \\
0.411\end{array}$ & $\begin{array}{l}(0.078) \\
(0.074)\end{array}$ \\
\hline $\begin{array}{l}\text { Fumarase } \\
\left(\mu \mathrm{W} \cdot 10^{9} \mathrm{spz}\right)\end{array}$ & $\begin{array}{l}R R \\
r r\end{array}$ & $\begin{array}{l}0.734 \\
0.553\end{array}$ & $\begin{array}{l}(0.101) \\
(0.119)\end{array}$ & $\begin{array}{l}0.655 \\
0.463\end{array}$ & $\begin{array}{l}(0.063) \\
(0.025)\end{array}$ & $\begin{array}{l}0.567 \\
0.804\end{array}$ & $\begin{array}{l}(0.037) \\
(0.227)\end{array}$ & $\begin{array}{l}0.368 \\
0.362\end{array}$ & $\begin{array}{l}(0.187) \\
(0.187)\end{array}$ \\
\hline
\end{tabular}


lates (1.8 $\mathrm{ml}$ in $R R$ vs $2.44 \mathrm{ml}$ in $\mathrm{rr}$ ) and sperm motility (14.7 vs 47.4). The day of collection, however, had no influence upon sperm motility, while the volume of the semen and the total number of sperm per ejaculate were significantly decreased from days 1 to 4 . The differences found in the sperm concentration from days 1 to 4 were also significant but not clearly related to the day of semen collection.

b) Biochemical assays. - The day of collection significantly influenced the ATP-ase and the fumarase activities. The ATP-ase was highest on day 1 and then became relatively stable in both genotypes. The fumarase activity decreased from day 1 to day 4 in both genotypes but was exceptionally high on day 3 in $r r$ cockerels, which explained the days $x$ genotype interaction for this semen characteristic,

Significant differences between genotypes were observed in the ATP-ase and acrosine activities, the first being higher in the $r r$ cockerels while the second was, ty contrast, lower in this strain.

TABLE 2

« $F$ » values obtained by analysis of variance of the characteristics of ejaculates during the first four days (collection by massage)

\begin{tabular}{|c|c|c|c|c|c|c|c|c|c|c|}
\hline $\begin{array}{c}\text { Factors } \\
\text { of variations }\end{array}$ & $\begin{array}{l}\text { Degrees } \\
\text { of } \\
\text { freedom }\end{array}$ & $\begin{array}{l}\text { Sample } \\
\text { volume }\end{array}$ & $\begin{array}{c}\text { No. } \\
\text { sperm } / \mathrm{ml}\end{array}$ & $\begin{array}{l}\text { Total no. } \\
\text { sperm per } \\
\text { sample }\end{array}$ & $\begin{array}{c}\text { Moti- } \\
\text { lity }\end{array}$ & $\begin{array}{l}\text { Uric } \\
\text { acid }\end{array}$ & $\begin{array}{c}\text { Acid } \\
\text { phospha- } \\
\text { tase }\end{array}$ & $\begin{array}{l}\text { ATP- } \\
\text { ase }\end{array}$ & $\begin{array}{l}\text { Acro- } \\
\text { sine }\end{array}$ & $\begin{array}{c}\text { Fuma- } \\
\text { rase }\end{array}$ \\
\hline Collection day & $3-13$ & 45.3 & 5.9 & 32.8 & $\begin{array}{l}1.1 \\
\text { NS }\end{array}$ & $\begin{array}{l}2.7 \\
\text { NS }\end{array}$ & $\begin{array}{l}2.4 \\
\text { NS }\end{array}$ & $\begin{array}{l}5.5 \\
*\end{array}$ & $\begin{array}{l}1.7 \\
\text { NS }\end{array}$ & $\begin{array}{l}17.6 \\
* * *\end{array}$ \\
\hline Comb genotype & $1-6$ & 12.7 & $\begin{array}{l}0.5 \\
\text { NS }\end{array}$ & $\begin{array}{l}2.7 \\
\text { NS }\end{array}$ & $\underset{* * *}{57.4}$ & $\begin{array}{c}0.1 \\
\text { NS }\end{array}$ & $\begin{array}{l}0.2 \\
\text { NS }\end{array}$ & $\underset{*}{10.5}$ & $\begin{array}{l}8.6 \\
*\end{array}$ & $\begin{array}{l}0.3 \\
\text { NS }\end{array}$ \\
\hline $\begin{array}{l}\text { Within genotype } \\
\text { sperm sample }\end{array}$ & $6-64$ & - & 260.0 & 214.0 & $\begin{array}{l}1.7 \\
N S\end{array}$ & $\begin{array}{l}18.7 \\
* * *\end{array}$ & $\begin{array}{l}0.3 \\
\text { NS }\end{array}$ & $\underset{*}{2.6}$ & $\begin{array}{c}14.2 \\
* * *\end{array}$ & $\begin{array}{l}17.9 \\
* * *\end{array}$ \\
\hline Days $\times$ genotype & $3-12$ & NS & $\begin{array}{l}1.2 \\
N S\end{array}$ & $\begin{array}{l}0.5 \\
\text { NS }\end{array}$ & $\begin{array}{l}0.3 \\
\text { NS }\end{array}$ & $\underset{* *}{10.3}$ & $\begin{array}{l}2.6 \\
\text { NS }\end{array}$ & $\begin{array}{l}1.0 \\
\text { NS }\end{array}$ & $\begin{array}{l}1.2 \\
\text { NS }\end{array}$ & $\begin{array}{l}8.8 \\
* *\end{array}$ \\
\hline $\begin{array}{l}\text { Days } \times \text { sample within } \\
\text { genotype }\end{array}$ & $18-64$ & - & $\underset{* * *}{13.2}$ & $\begin{array}{l}33.6 \\
* * *\end{array}$ & 1.7 & $\begin{array}{c}14.2 \\
* * *\end{array}$ & $\begin{array}{l}0.5 \\
\text { NS }\end{array}$ & $\begin{array}{l}1.4 \\
\text { NS }\end{array}$ & $\underset{* * *}{6.3}$ & $\underset{* * *}{5.0}$ \\
\hline
\end{tabular}

2. Comparison between the results of the two semen collection fechniques. - The following are the results obtained for semen collection by massage compared to those obtained for semen collected at the tip of the papillae. Between-genotype differences are also considered (table 3).

a) Biophysical results. - The volume of the semen collected at the tip of the papillae was significantly higher than that of samples collected by massage technique. The same trend was observed for sperm concentration, and thus, in the total number of sperm per sample (3.34 and $4.64 \times 10^{9}$ sperm vs 10.57 and $8.85 \times 10^{9}$ sperm in RR and rr cockerels, respectively). Interestingly, there were no significant differences between the techniques for motility results.

Irrespective of the semen collection technique, the volume of the semen samples was higher in $r r$ than in $R R$ cockerels, while the reverse was observed for the sperm 
concentration results. This resulted in a non-significant difference between strains for the total number of sperm per sample. Sperm motility was more than three times higher in $r r$ than in $R R$ cockerels.

TABLE 3

Characteristics of RR and rr cockerels ejaculates obtained by two methods

\begin{tabular}{|c|c|c|c|c|c|c|}
\hline \multirow{2}{*}{$\begin{array}{c}\text { Characteristics } \\
\text { studied }\end{array}$} & \multirow{2}{*}{$\begin{array}{l}\text { Comb } \\
\text { geno- } \\
\text { type }\end{array}$} & \multicolumn{2}{|c|}{$\begin{array}{l}\text { Day 4, normal } \\
\text { collections }\end{array}$} & \multicolumn{2}{|c|}{$\begin{array}{l}\text { Day 5, papillary } \\
\text { collections } \\
\text { (post-mortem) }\end{array}$} & \multirow{2}{*}{$\begin{array}{c}\text { Statistical analysis } \\
\text { of significance } \\
\text { a : D/collection method } \\
\text { F1/F2 } \\
\text { b : Comb genotype }\end{array}$} \\
\hline & & $\bar{x}$ & (s) & $\bar{x}$ & (s) & \\
\hline Sample volume (ml) & $\begin{array}{l}R R \\
r r\end{array}$ & $\begin{array}{l}1.238 \\
2.075\end{array}$ & $\begin{array}{l}(0.206) \\
(0.189)\end{array}$ & $\begin{array}{l}2.400 \\
2.650\end{array}$ & $\begin{array}{l}(0.408) \\
(0.681)\end{array}$ & $\begin{array}{l}a:\langle F\rangle=17.053^{* *} \\
b:\langle F\rangle=6.681^{*}\end{array}$ \\
\hline No. sperm/ml $\left(.10^{9}\right)$ & $\begin{array}{l}R R \\
r r\end{array}$ & $\begin{array}{l}2.775 \\
2.225\end{array}$ & $\begin{array}{l}(0.773) \\
(0.492)\end{array}$ & $\begin{array}{l}4.392 \\
3.267\end{array}$ & $\begin{array}{l}(0.504) \\
(0.482)\end{array}$ & $\begin{array}{l}a: 《 F\rangle=21.095^{* * *} \\
b: \| F »=8.396^{*}\end{array}$ \\
\hline $\begin{array}{l}\text { Total no. sperm/ } \\
\text { sample }\left(.10^{9}\right)\end{array}$ & $\begin{array}{l}R R \\
r r\end{array}$ & $\begin{array}{l}3.338 \\
4.643\end{array}$ & $\begin{array}{l}(0.524) \\
(1.245)\end{array}$ & $\begin{array}{c}10.574 \\
8.858\end{array}$ & $\begin{array}{l}(2.317) \\
(3.654)\end{array}$ & $\begin{array}{l}a:\left\langle F \|=25.550^{* * *}\right. \\
b:\langle F \|=0.033 \mathrm{NS}\end{array}$ \\
\hline Motility & $\begin{array}{l}R R \\
r r\end{array}$ & $\begin{array}{l}14.7 \\
51.1\end{array}$ & $\begin{array}{l}(10.2) \\
(12.4)\end{array}$ & $\begin{array}{l}16.3 \\
52.2\end{array}$ & $\begin{array}{l}(7.3) \\
(9.3)\end{array}$ & $\begin{array}{l}a:\langle F\rangle=1.040 \mathrm{NS} S \\
b:\langle F\rangle=36.038^{* * *}\end{array}$ \\
\hline Uric acid (mg/l) & $\begin{array}{l}R R \\
r r\end{array}$ & $\begin{array}{l}319 \\
424\end{array}$ & $\begin{array}{l}(162) \\
(95)\end{array}$ & $\begin{array}{r}124 \\
97\end{array}$ & $\begin{array}{l}(39) \\
(23)\end{array}$ & $\begin{array}{l}\mathrm{a}:\left\langle\mathrm{F} \|=29.159^{* * *}\right. \\
\mathrm{b}:\langle\mathrm{F} \|=0.644 \mathrm{NS}\end{array}$ \\
\hline $\begin{array}{l}\text { Acid phosphatase } \\
(\mu \mathrm{M} / \mathrm{ml})\end{array}$ & $\begin{array}{l}R R \\
r r\end{array}$ & $\begin{array}{l}2.041 \\
2.417\end{array}$ & $\begin{array}{l}(0.107) \\
(0.483)\end{array}$ & $\begin{array}{l}3.491 \\
3.115\end{array}$ & $\begin{array}{l}(1.343) \\
(0.376)\end{array}$ & $\begin{array}{l}a:\langle F\rangle=7.965^{*} \\
b:\langle F\rangle=0.003 \mathrm{NS}\end{array}$ \\
\hline ATP ase $(\mu \mathrm{M} / \mathrm{ml})$ & $\begin{array}{l}R R \\
r r\end{array}$ & $\begin{array}{l}1.128 \\
1.525\end{array}$ & $\begin{array}{l}(0.180) \\
(0.146)\end{array}$ & $\begin{array}{l}1.216 \\
1.568\end{array}$ & $\begin{array}{l}(0.264) \\
(0.181)\end{array}$ & $\begin{array}{l}a:\langle F\rangle=0.854 \mathrm{NS} \\
b:\langle F\rangle=11.922^{* *}\end{array}$ \\
\hline $\begin{array}{l}\text { Acrosine } \\
\left(\mu \mathrm{M} / .10^{9} \mathrm{spz}\right)\end{array}$ & $\begin{array}{l}R R \\
r r\end{array}$ & $\begin{array}{l}0.404 \\
0.411\end{array}$ & $\begin{array}{l}(0.078) \\
(0.074)\end{array}$ & $\begin{array}{l}0.520 \\
0.462\end{array}$ & $\begin{array}{l}(0.101) \\
(0.065)\end{array}$ & $\begin{array}{l}a:\langle F \|=3.565 \mathrm{NS} \\
b:\langle F \|=0.555 \mathrm{NS}\end{array}$ \\
\hline $\begin{array}{l}\text { Fumarase } \\
\left(\mu \mathrm{M} .10^{9} \mathrm{spz}\right)\end{array}$ & $\begin{array}{l}R R \\
r r\end{array}$ & $\begin{array}{l}0.368 \\
0.362\end{array}$ & $\begin{array}{l}(0.187) \\
(0.063)\end{array}$ & $\begin{array}{l}0.597 \\
0.498\end{array}$ & $\begin{array}{l}(0.237) \\
(0.127)\end{array}$ & $\begin{array}{l}a:\langle F\rangle=3.288 \mathrm{NS} \\
\mathrm{b}:\langle F\rangle=0.973 \mathrm{NS}\end{array}$ \\
\hline
\end{tabular}

b) Biochemical assays. - A considerable between-technique difference was observed for the uric acid concentration which was 3 to 4 times higher in the massage samples than in the papillae samples. The acid phosphatase activity was significantly higher in the latter case than in the former. No significant differences were observed for the other enzymes (ATP-ase, acrosine, fumarase).

Only one significant difference was observed between the genotypes: ATP-ase was 25 to 30 p. 100 higher in $r r$ than in $R R$ cockerels.

3. Correlations between semen characteristics (table 4).

a) Particle-linked enzymes. - Positive correlations were observed between the activities of the particle-linked enzymes in the seminal plasma and the volume of the semen samples for $R R$ cockerels and for $R R+r r$ cockerels taken together. 


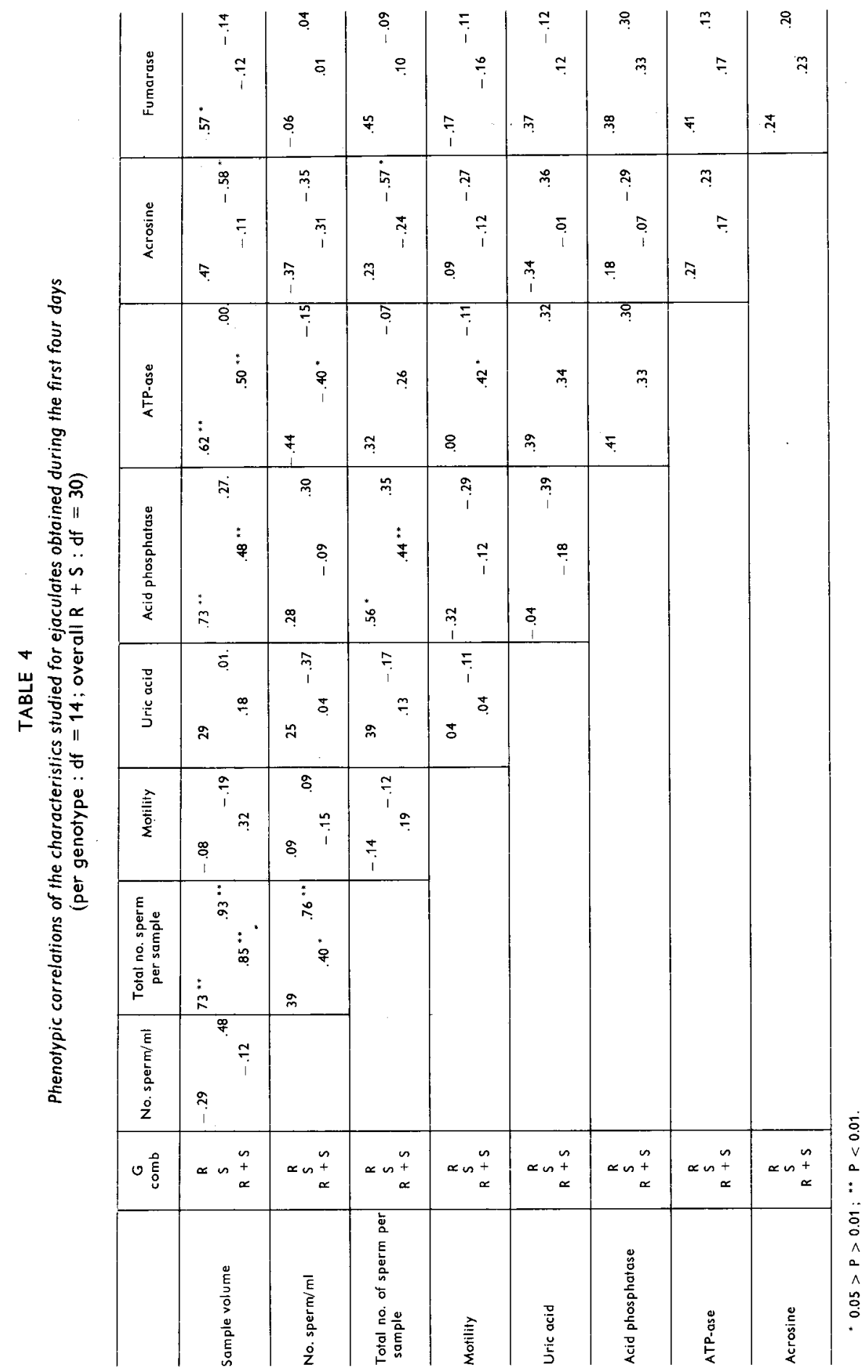


The ATP-ase activity was negatively correlated with the sperm concentration, but positively correlated with motility in $R R+r r$ cockerels taken together. However, no significant correlation was found within individual genotypes.

Acid phosphatase was significantly correlated with the total number of sperm per semen sample but not with the sperm concentration.

b) Intraspermic enzymes. - In the case of $r$ cockerels only, there was a negative correlation between acrosine activity and either the volume of the semen samples or the total number of sperm in these samples. The fumarase activity was positively correlated with the semen sample volume, but only in the RR cockerels.

\section{Discussion.}

The present results agree with previous observations (Petitjean and Cochez, 1966). While the $R R$ genotype has no significant influence upon the amount of semen, this genotype strongly depresses the sperm motility observed after dilution and storage. In the present work, similar results were found for semen directly collected from the papillae. The lower motility found in the sperm from $R R$ cockerels is therefore not due to contamination of the semen at the time of collection.

The concentration of uric acid found in the seminal plasma from semen collected by either the massage method ( $350 \mathrm{vs} 375 \mathrm{mg} / \mathrm{l}$ in $R R$ vs rr cockerels, respectively). or directly from the papillae (124 vs $97 \mathrm{mg} / \mathrm{l}$, respectively) are the same or slightly higher than those found by Lake (1971) in semen samples either contaminated (375 $\mathrm{mg} / \mathrm{l}$ ) or uncontaminated $(78 \mathrm{mg} / \mathrm{l})$ with transparent fluid. As the difference between $R R$ and $r$ cockerels for uric acid concentration is not statistically significant, this component would not appear to be implicated in the low fertility found in $R R$ cockerels.

It is known (Lake, 1962) that acid phosphatases are secreted throughout the genital tract of the cockerel but the relationships between these enzymes and the spermatozoa are still obscure. Our observations on particle-linked acid phosphatase cannot clarify the relationship between the activity of this enzyme and the subnormal motility and fertility found in the spermatozoa from $R R$ cockerels. It was found that the acid phosphatase activity is $1.5 \mathrm{higher}$ in semen samples collected directly from papillae than in those collected by massage. For the latter, there are positive correlations between the activity of acid phosphatase and either the volume of ejaculates or their total number of spermatozoa. However, ATP-ase activity varied independently of acid phosphatase activity yet both enzymes are particle-linked. ATP-ase activity depends upon the semen collection method and its activity is positively correlated with the volume of ejaculates but negatively correlated with their sperm concentration. Although ATP-ase activity and motility was less in $R R$ than in rr cockerels, no correlation was found between ATP-ase activity and motility.

No consistent relationships were found between acrosin activity and either genotype or fertilizing ability or semen collection method. The same was true for fumarase activity, despite a previous report of depressed fumarase activity in $R R$ cockerels (Buckland et al., 1968). Differences between strains and techniques (extraction and assay of the enzyme) might explain the discrepancy. 


\section{Conclusion.}

This work has confirmed that the motility of the spermatozoa is depressed in $R R$ cockerels. This depression is not due to the semen collection method, although this modifies the semen characteristics.

ATP-ase activity, like motility, is depressed in RR cockerels : this activity could therefore be useful in predicting the fertilizing ability of the spermatozoa or for diagnosing the status of the genital tract of cockerels.

Workshop on «Avian male reproduction » Nouzilly, France, June 1980.

Acknowledgements. - The authors are indebted to M. de Reviers and J. B. Williams for helpful assistance in the preparation of the manuscript and English translation.

Résumé. Les spermes de coqs $R R$ (subfertiles) et $r r$ (fertiles) sont éfudiés comparativement. Les échantillons sont obtenus d'une part, par massage abdominal, d'autre part, directement à la papille. Les quantités de spermatozoïdes collectées ne diffèrent pas significativement entre les génotypes et ceci pour les deux modes de collecte mis en œuvre. La motilité subnormale des spermatozoïdes des coqs $R R$ est très nette quelle que soit la technique de prélèvement du sperme. Le mode de collecte influe considérablement le taux d'acide urique (massage $>$ papille), mais sans effet significatif du génotype. L'activité de l'ATP-ase est significativement influencée par le génotype $(r r>R R)$ tandis que le mode de collecte a une action significative sur l'activité de la phosphatase acide (papille $>$ massage). Le mode de collecte et le génotype n'ont pas d'effet significatif sur l'activité de la fumarase. II en est de même pour le mode de collecte de l'acrosine, mais une différence significative de l'activité de cette enzyme est observée entre les génotypes $(R R>r r)$. Les corrélations entre les caractères observés sont étudiées.

\section{References}

BUCKLAND R. B., WILCOX F. H., SHAFFNER C. S., 1968. Influence of homozygosity for rose comb on fumarase, aconitase, isocitric dehydrogenase and malic dehydrogenase activity in spermalozon of the domestic fowl (Gallus domesticus). J. Reprod. Fertil., 18, 89-95.

COCHEZ L. P., 1951. Un facteur d'infertilité, équilibré par la sélection chez la Wyandotte blanche. C. R. IXe Congr. mond. Avic., 1, 122-128.

CRAWFORD R. D., SMYTH J. R., 1964a. Studies of the relationship between fertility and the gene for rose comb in the domestic fowl. 1. The relationship between comb genotype and fertility. Poult. Sci., 43, 1009-1017.

CRAWFORD R. D., SMYTH J. R., 1964b. Studies of the relationship between fertility and the gene for rose comb in the domestic fowl. 2. The relationship between genotype and duration of fertility. Poult. Sci., 43, 1018-1026.

CRAWFORD R. D., SMYTY J. R., 1964c. Semen quality and the gene for rose comb in the domestic fowl. Poult. Sci., 43, 1551-1557.

ERLANGER B. F., KOKOWSY N., COHEN W, 1961. The preparation and properties of two new chromogenic substrates of trypsin. Arch. Biochem. Biophys., 95, 271-278.

HILL R. L., BRADSHOW R. A., 1969. Fumarase. In Methods in enzymology, COLONICK S. P., KAPLAN N. O., GINSBURG F., vol. XIII, 91-98. Acad. Press, N.Y. and London. 
HORGAN D. J., TUME R. K., NEWBOLD A. P., 1972. Simple spectrophotometric estimation of ATPase and calcium uptake activities of sarcoplasmic reticulum preparations. Analyt. Biochem., 48 , 147-152.

LAKE P. E., 1962. Histochemical demonstration of phosphomonoesterases activities in the genital tract of the domestic cock. J. Reprod. Fert., 3, 356-362.

LAKE P. E., 1971. Cited from D. J. BELL, B. M. FREEMAN, Physiology and biochemistry of the domestic fowl, 1411-1447. Acad. Press, London and N.Y.

PETITJEAN M. J., 1970. Résultats expérimentaux sur la subfertilité liée à la crête rosacée chez le coq. C. R. XIXe Congr. mond. Avic., 2, 313-318.

PETITJEAN M. J., COCHEZ L. P., 1966. A propos de la subfertilité des coq-homozygotes pour le gène « R » (crête rosacée). C. R. XIlle Congr. mond. Avic., 125-130.

PEYRE A., MONDOT S., PETITJEAN M. J., 1968. Quelques caractéristiques biophysiques et biochimiques du sperme de coqs de deux souches homozygotes « RR » et « rr ». C. R. Soc. Bio!., 162, 1991-1994.

PRAETORIUS E., 1963. In BERGMEYER H. U. Methods of enzymatic analysis, 500-501. Verlag ChemieGBMH-Wheinheim/Bergstr. Acad. Press N.Y. and London. 